Jurnal Interpretasi Hukum | ISSN: 2746-5047

Vol. 2, No. 3-Desember 2021, Hal. 651-655| Tersedia online di

https://www.ejournal.warmadewa.ac.id/index.php/juinhum

DOI: https://doi.org/10.22225/juinhum.2.3.4167.651-655

\title{
TINJAUAN YURIDIS TERHADAPTINDAK PIDANA PENIPUAN JUAL BELI TANAH (Studi Kasus : Putusan No. 74/Pid.B/2017/PN Gin)
}

\author{
Ngakan Made Wira Diputra, I Nyoman Gede Sugiartha, Luh Putu Suryani \\ Fakultas Hukum, Universitas Warmadewa, Denpasar-Bali, Indonesia \\ ramangakan@yahoo.com, nyomansugiartha14@gmail.com, putusuryani099@gmail.com
}

\begin{abstract}
Abstrak
Tindak pidana di muka bumi ini tidak akan pernah berakhir. Perlakuan pidana yang paling sering terjadi di lingkungan masyarakat yaitu tindak pidana penipuan yang berkaitan dengan suatu objek. Tindak pidana penipuan sudah diatur mulai dari pasal 378 sampai pasal 395 KUHP. Penelitian ini bertujuan untuk mengkaji sanksi pidana terhadap tindak pidana penipuan transaksi jual beli tanah dan mengungkapkan pertimbangan majelis hakim terhadap pelaku tindak pidana penipuan transaksi jual beli tanah menurut studi kasus: Putusan No. 74/Pid.B/2017/PN Gin. Penelitian ini menggunakan metode penelitian hukum normatif dengan pendekatan Perundang-undangan dan pendekatan studi kasus. Bahan hukum yang digunakan adalah bahan hukum primer dan sekunder yang dikumpulkan dengan teknik kepustakaan dan wawancara. Selanjutnya data penelitian diolah dan dianalisis secara kualitatif deskriptif. Hasil penelitian mengungkapkan bahwa sanksi pidana yang diterapkan berupa pidana pokok dengan melihat surat dakwaan penuntut umum yang lebih menerapkan pada pasal 378 KUHP sehingga dalam studi kasus putusan tersebut terdakwa dijatuhi pidana ahun penjara. Majelis Hakim mengambil keputusan tersebut setelah mendengar keterangan dari terdakwa, para saksi korban, dan barang bukti yang ditunjukkan oleh penuntut umum.
\end{abstract}

Kata Kunci: Sanksi Pidana, Penipuan, Tanah

\begin{abstract}
Crime on this earth will never end. The most frequent criminal treatment in the community is the crime of fraud related to an object. The crime of fraud has been regulated starting from Article 378 to Article 395 of the Criminal Code. This study aims to examine the criminal sanctions against the crime of fraud in the sale and purchase of land and reveal the judges' considerations against the perpetrators of the crime of fraud in the sale and purchase of land according to the case study: Decision No. 74/Pid.B/2017/PN Gin. This study uses a normative legal research method with a legislation approach and a case study approach. The legal materials used are primary and secondary legal materials collected by library and interview techniques. Furthermore, the research data was processed and analyzed descriptively qualitatively. The results of the study revealed that the criminal sanction applied was in the form of a principal sentence by looking at the indictment of the public prosecutor which applied more to Article 378 of the Criminal Code so that in the case study the defendant was sentenced to a year in prison. The Panel of Judges made this decision after hearing statements from the defendant, victim witnesses, and evidence presented by the public prosecutor.
\end{abstract}

Keywords: Criminal Sanctions, Fraud, Land

\section{PENDAHULUAN}

Tindak pidana sudah menjadi kasus yang tidak pernah hentinya dan tidak akan pernah berakhir seiring dengan perkembangan sosial yang terjadi didalam masyarakat. Undang-undang Dasar Negara Kesatuan Republik Indonesia Tahun 1945 juga membahas persamaan di depan hukum, yaitu dalam pasal 27 ayat (1) yang berbunyi segala warga negara bersamaan kedudukannya di dalam hukum dan pemerintahan dan wajib menjunjung hukum dan pemerintahan itu dengan tidak ada kecualinya. 
Dengan demikian maka haruslah setiap orang diperlakukan sama dihadapan hukum tanpa memandang ras, suku, agama, kebangsaan, dan lain-lain tanpa hak keistimewaan, dan diskriminasi. Kasus terjadinya suatu tindak pidana sangat sering dialami dalam lingkungan sekitar, dan salah satunya yaitu tindak pidana penipuan. Tindak pidana penipuan merupakan suatu bentuk tindak pidana yang digolongkan kejahatan terhadap harta benda orang atau dikatakan sebagai perbuatan curang (Satyastuti et al., 2016). Untuk menanggulangi terjadinya tindak pidana terutama tindak pidana penipuan yang semakin meluas, maka pemahaman yang sejalan sangat diperlukan dengan ketentuan yang tertuang dalam Kitab Undang-undang Hukum Pidana.

Hukum pidana disusun sedemikian rupa sebagai aturan yang tertulis, untuk diterapkan sebagai hukum positif, akan tetapi lebih efektif dan dirasa dapat tercapainya keadilan apabila pelaksanaannya sesuai dengan yang dimaksud oleh pembentuk Undang- undang (Chazawi, 2002).

Salah satu kasus tindak pidana penipuan yang sering terjadi didalam masyarakat sekitar adalah tindak pidana penipuan dalam hal transaksi jual beli suatu objek (Yahman, 2014). Terjadinya tindakan penipuan ini karena didalam lingkungan masyarakat masih sering terjadi jual beli suatu objek tanpa mencari tahu kebenaran ataupun asal usul dari objek tersebut, sehingga kedepannya suatu transaksi jual beli yang dilakukan secara sembarangan akan menimbulkan suatu masalah yang berujung kepada tindak pidana apa lagi jika tanah tersebut masih bersangkutan dengan pihak lembaga lain seperti perbankan maka ini akan jadi masalah kemudia apa bila diperjual belikan (Azkia Dwi Ambarwati, Pieter E. Latumeten, 2016) \& (Cipta et al., 2020). Berdasarkan fenomena yang telah diuraikan dari penelitian terdahulu, maka ingin melaukan penelitian yang bertujuan untuk mengkaji sanksi pidana terhadap tindak pidana penipuan transaksi jual beli tanah dan mengungkapkan pertimbangan majelis hakim terhadap pelaku tindak pidana penipuan transaksi jual beli tanah menurut studi kasus: Putusan No. 74/Pid.B/2017/PN Gin

\section{METODE PENELITIAN}

Penelitian ini didesain menggunakan peneltia hukum normatif dengan pendekatan perundangundangan dan konseptual. Adapun data yang digunakan adala data hukum primer dan sekunder yang dikumpulkan dengan teknik wawncara dan kepustakaan. Data primer adalah diperoleh dari beberapa sumber yaitu Undang-undang, selanjutnya data sekunder merupakan data pendukung dari data utama yang diperoleh dari kegiatan membaca beberapa teori hukum. Setelah data terkumpul maka dianalisis secara kulaitatif deskriptif secara sistematis dan terarah sebagai cara untuk mengembangkan, mendapatkan, dan menguji kebenaran suatu sebab nilai ilmiah dalam suatu penelitian yang tidak dapat dipisahkan dari metodologi yang digunakan (Moleong, 2005).

\section{HASIL DAN PEMBAHASAN}

\section{Sanksi Pidana Terhadap Pelaku Tindak Pidana Penipuan Transaksi Jual Beli Tanah}

Sanksi pidana yaitu ancaman yang bersifat siksaan dan penderitaan. Bersifat penderitaan, karena sanksi atau pemidanaan itu dimaksudkan sebagai hukuman kepada individu yang melakukan pelanggaran terhadap kepentingan hukum yang dilindungi hukum pidana (Gunadi \& Efendi, 2011).

Pada pasal 10 KUHP memuat ketentuan sanksi pidana yang bisa dijatuhkan kepada pelaku tindak pidana, yaitu:

1. Berupa pidana okok meliputi pidana mati, pidana penjara, pidana kurungan, pidana denda, pidana tutupan.

2. Pidana tambahan, meliputi pencabutan hak-hak tertentu, pidana perampasan barang tertentu, pidana pengumuman putusan hakim

Transaksi adalah kegiatan yang dilakukan seseorang yang mempunyai dampak perubahan terhadap harta atau keuangan yang dimiliki baik itu bertambah ataupun berkurang. Pasal 1457 KUHPer, mengatur tentang yang dimaksud jual beli yaitu suatu perjanjian dengan mana pihak yang satu mengikatkan dirinya untuk menyerahkan suatu benda dan pihak lain membayar harga yang telah dijanjikan. Pasal 1458 KUHPer berbunyi jual beli dianggap telah terjadi antara kedua belah pihak, seketika setelah orang-orang ini mencapai sepakat tentang kebendaan tersebut dan harganya, meskipun kebendaan tersebut belum diserahkan maupun harganya belum dibayar. Jual beli itu, satu pihak sebagai penjual mengikatkan dirinya kepada pihak lainnya yaitu pembeli untuk memberikan suatu benda dengan memperoleh pembayaran dari pihak pembeli sejumlah tertentu berupa uang 
(R.M.Suryodiningrat, 1996). Selanjutnya, jual beli merupakan sebuah perjanjian berupa timbal balik, dimana selaku penjual yaitu pihak pertama sepakat akan memberikan hak milik suatu barang dan dari pembeli yaitu pihak kedua sepakat membayarkan berupa sejumlah uang yang telah disepakati (Cipta et al., 2020).

Tindak pidana penipuan, tergolong kedalam kejahatan harta benda dan di rumuskan pada KUHP BAB XXV, mulai pasal 378 sampai pasal 395. Pasal 378 KUHP mengatur mengenai tindak pidana penipuan berbunyi barang siapa dengan maksud untuk menguntungkan diri sendiri atau orang lain secara melawan hukum, dengan memakai nama palsu atau martabat palsu dengan tipu muslihat, atau rangkaian kebohongan, menggerakkan orang lain untuk menyerahkan barang sesuatu kepadanya, atau supaya memberi hutang maupun menghapuskan piutang diancam karena penipuan dengan pidana penjara paling lama empat tahu. Penerapan sanksi pidana harus ada unsur-unsur yang dipenuhi atau syarat harus dipenuhi jika melakukan tindak pidana penipuan yang meliputi unsur objektif dan unsur subjektif.

Berdasarkan Putusan Perkara No. 74/Pid.B/2017/PN Gin. Tindak pidana penipuan ini diperkirakan terjadi sekitar bulan April tahun 2015, diketahui terdakwa dalam kasus ini bernama I Gusti Ngurah Rai Suliatmaja alias Ngurah Kembung. Berdasarkan hasil analisis diketahui bahwa tanah yang terdakwa jual adalah milik Saksi A.A Gede Jaya yang di beli dari I Wayan Suarjana yang berlokasi di Br. Temesi, Desa Temesi, Kec/Kab. Gianyar seluas 15 are pada tahun 1997. Suratsurat tanah tersebut masih berada di kantor Notaris Arini dalam proses balik nama, namun masih terhambat masalah biaya, sehingga Saksi A.A Gede Jaya meminta bantuan kepada I Ketut Alit untuk membantu memasarkan tanahnya yang dibeli dari I Wayan Suarjana terletak di Br. Temesi, Desa Temesi, Kec/Kab. Gianyar. Terdakwa diadili dengan putusan:

1. Menyatakan terdakwa I Gusti Ngurah Rai Suliatmaja alias Ngurah Kembung, terbukti secara sah dan meyakinkan bersalah telah melakukan tindak pidana "Penipuan".

2. Menjatuhkan pidana kepada terdakwa, dengan pidana penjara selama dua tahun

3. Menetapkan barang bukti berupa 1 (satu) lembar kwitansi tertanggal 8 April 2016 dengan nilai Rp. 55.000.000 (lima puluh lima juta rupiah) telah diterima dari Ni Ketut Suardewi ditandatangani oleh I Gusti Ngurah Rai Suliatmaja; 1 (satu) lembar kwitansi tertanggal 8 April 2016 dengan nilai Rp. 30.000 .000 (tiga puluh juta rupiah) telah diterima dari I Nengah Padmayasa ditandatangani oleh I Gusti Ngurah Rai Suliatmaja; 1 (satu) lembar kwitansi tertanggal 8 April 2016 dengan nilai Rp. 12.000.000 (dua belas juta rupiah) telah diterima dari Kadek Mudiana ditandatangani oleh I Gusti Ngurah Rai Suliatmaja. Dikembalikan kepada yang berhak yaitu saksi Ni Ketut Suarde wi.

4. Membebankan kepada terdakwa untuk membayar biaya perkara sejumlah Rp. 5.000 (lima ribu rupiah).

Tuntutan yang tercantum dalam dakwaan penuntut umum lebih mengarah ke pasal 378 KUHP yaitu penipuan. Dibuktikan dengan perbuatan terdakwa yang memenuhi semua unsur-unsur objektif maupun unsur subjektif yang ada dalam ketentuan pasal 378 KUHP tersebut.

\section{Pertimbangan Majelis Hakim Terhadap Pelaku Tindak Pidana Penipuan Transaksi Jual Beli Tanah Menurut Studi Kasus: Putusan No. 74/Pid.B/2017/Pn Gin}

Hakim pada umunya bertugas menerapkan hukum dalam hal konkret, yaitu suatu tindakan yang diberikan oleh pengadilan yang bertujuan mendapatkan perlindungan hukum guna mencegah tindakan menghakimi sendiri (Mertokusumo, 2004). Hakim sebelum memutus perkara akan mempelajari dakwaan dari penuntut umum, dan juga bila ada barang bukti yang mendukung suatu persidangan tersebut, dan tentunya hakim juga akan medengarkan keterangan dari terdakwa didalam persidangan. Berdasarkan kasus diatas, Hakim melihat bahwa tindakan terdakwa sudah memenuhi seluruh unsur subjektif maupun unsur objektif yang ada dalam pasal 378 KUHP, sehingga Ngurah Kembung terbukti sah dan menyakinkan melakukan tindak pidana penipuan.

Dari permasalahan tersebut layak dijatuhkannya sanksi pidana kepada terdakwa dalam kasus di atas sudah tepat, karena salah satu tujuan dari adanya sanksi pidana adalah mendidik atau membenahi siapa saja yang menandakan suka melakukan kejahatan supaya menjadi individu yang baik dan bermanfaat bagi masyarakat, terkecuali jika seseorang mengulangi tindakan kejahatannya untuk yang ketiga kalinya barulah Majelis Hakim harus memberikan sanksi pidana yang lebih berat kepada 
pelaku agar merasa lebih jera. Majelis Hakim dalam persidangan juga tidak melihat suatu hal yang bisa melepaskan terdakwa dari pertanggung jawabannya, seperti berupa alasan pembenar maupun alasan pemaaf.

Menurut Lamintang, (1997) beberapa syarat seseorang dapat dipertanggungjawabkan perbuatannya, diantaranya adalah Orang itu jiwanya harus stabil agar ia mengerti atau menyesali akibat dari perbuatannya; Orang harus menginsyafi bahwa yang ia lakukan dilarang menurut tata cara kemasyarakatan; Kehendak orang tersebut harus dapat menentukan perbuatannya.

KUHP terdapat beberapa pasal yang memuat alasan-alasan yang dapat menghilangkan sifat tindak pidana itu sendiri seperti alasan pemaaf dan alasan pembenar yaitu dalam pasal 44,48,49,50,51. Tidak ada alasan bagi terdakwa untuk bisa lepas dari sanksi yang dijatuhkan Majelis Hakim kepadanya, karena keadaan terdakwa saat itu sehat secara jasmani dan rohani, maka dari itu terdakwa wajib untuk menjalankan sanksi yang diberikan selama waktu tertentu.

Hal-hal yang memberatkan yaitu tindakan terdakwa menyebabkan para saksi korban mengalami kerugian dan terdakwa diketahui telah melakukan tindak pidana sebelumnya dan sedang menjalani hukuman pidana penjara di Rutan Gianyar berdasarkan Putusan Pengadilan Negeri Bangli No. 24/Pid.B/2016/PN Bli tanggal 30-06-2016.

Hal-hal yang meringankan terdakwa mengakui perbuatannya; Terdakwa bersikap sopan selama persidangan; Terdakwa diketahui mempunyai anak yang masih kecil. Maksimum ancaman pidana dikurangi sepertiga mengenai lamanya peringanan pidana, maksimum pidananya adalah pidana penjara lima belas tahun jika dalam ancaman pidana mati atau pidana seumur hidup (Arief, 2012). Ancaman maksimum pidana diperberat sepertiga terlebih dahulu, lalu hasil tersebut dikurangi sepertiga. Jika terdapat hal-hal yang meringankan dan memberatkan pidana secara bersamaan

\section{SIMPULAN DAN SARAN}

\section{Simpulan}

Berdasrkan analisis data, dapat disimpulkan bahwa sanksi pidana yang diterapkan kepada pelaku tindak pidana penipuan transaksi jual beli tanah sehubungan dengan putusan No. 74/Pid.B/2017/PN Gin dijatuhi pidana penjara selama dua tahun dan membayar biaya perkara sejumlah Rp. 5.000 (lima ribu rupiah). Keputusan ini diambil setelah mendengarkan keterangan dari semua pihak. Dakwaan penuntut umum telah memenuhi syarat formil suatu surat dakwaan dan fakta-fakta hukum yang ditemukan dalam persidangan, sehingga tindakan terdakwa menurut hukum telah sah memenuhi pasal 378 KUHP. Pertimbangan Majelis Hakim terhadap pelaku tindak pidana penipuan transaksi jual beli tanah putusan No. 74/Pid.B/2017/PN Gin yaitu Majelis Hakim sebelum memutus perkara sudah mendengarkan keterangan para saksi korban dan keterangan lisan dari terdakwa, dimana terdakwa membenarkan semua keterangan dari para saksi korban dan mengakui semua perbuatannya. Majelis Hakim juga telah melihat bahwa perbuatan terdakwa sudah memenuhi semua unsur atau elemen yang ada dalam pasal 378 KUHP baik unsur subjektif maupun unsur objektifnya. Terdakwa juga mendapat peringanan dan pemberatan sanksi karena terdakwa telah mengakui semua perbuatannya dan bersikap sopan dalam persidangan, serta terdakwa diketahui mempunyai anak-anak yang masih kecil. Sehingga Majelis Hakim menjatuhkan sanksi kepada terdakwa berupa pidana dua tahun penjara.

\section{Saran}

Adapun saran yang disampaikan peneliti yaitu penerapan sanksi yang dilakukan oleh aparat penegak hukum kepada pelaku kejahatan pidana penipuan agar lebih tegas dan ketat kepada para pelaku tindak pidana dalam memberikan sanksi pidana serta tidak pandang bulu dalam memberikan suatu sanksi pidana terhadap seseorang. Pertimbangan majelis Hakim dalam menjatuhkan sanksi pidana kepada terdakwa agar lebih ditingkatkan, sehingga nantinya masyarakat merasa lebih percaya dan aman kepada aparat penegak hukum dan tidak segan untuk meminta bantuan hukum sebagai cara untuk mendapatkan suatu keadilan.

\section{DAFTAR PUSTAKA}

Arief, N. B. (2012). Kebijakan Formulasi Ketentuan Pidana dalam Peraturan Perundang-Undangan. Semarang: Pustaka Magister.

Azkia Dwi Ambarwati, Pieter E. Latumeten, W. S. (2016). Perjanjian Pengikatan Jual Beli Hak Atas 
Tanah Yang Terikat Jaminan Bank. Jurnal Hukum \& Pembangunan, 4(7), 1-24.

Chazawi, A. (2002). Stelsel Pidana, Tindak Pidana, Teori-teori Pemidanaan\& Batas Berlakunya

Hukum Pidana Bagian I. Raja Grafindo Persada: Jakarta.

Cipta, R. A., Ngadino, \& Prabandari, A. P. (2020). Akta Pengikatan Jual Beli Tanah Sebelum

Dibuatnya Akta Pejabat Pembuat Akta Tanah. Notarius, 13(2), 890-905.

Gunadi, I., \& Efendi, J. (2011). Hukum Pidana. Jakarta. Prenadamedia Group.

Lamintang, P. A. . (1997). Dasar-DAsar Hukum Pidana Indonesia Bandung. Citra Aditya Bakti.

Mertokusumo, S. (2004). Mengenal Hukum: Suatu Pengantar. Liberty: Yogyakarta.

Moleong, L. J. (2005). Metode Penelitian Kualitatif. Remaja Rosdakarya.

R.M.Suryodiningrat. (1996). Perikatan-perikatan Bersumber Perjanjian. Tarsito: Bandung.

Satyastuti, N. W. R., Sari, C. A. T., \& Vaundra, V. A. (2016). Proses Penyelesaian Tindak Pidana

Desersi yang Dilakukan oleh Anggota Tentara Nasional Indonesia. Jurnal Verstek, 4(2), 10-17.

Yahman. (2014). Karakteristik Wanprestasi \& Tindak Pidana Penipuan. Jakarta. Kencana. 